Abstract No. 10IKC-32

\title{
PETROLOGY OF LAMPROITES FROM THE NUAPADA LAMPROITE FIELD, BASTAR CRATON, INDIA
}

\author{
Sahu ${ }^{*} \mathbf{N}^{1}$, Gupta $\mathrm{T}^{\mathbf{2}}$, Patel SC ${ }^{2}$, Khuntia DBK ${ }^{2}$, Thakur SS ${ }^{3}$ and Das SK \\ ${ }^{1}$ Directorate of Geology, Government of Odisha, Bhuvigyan Bhawan, Bhubaneshwar 751001, India \\ ${ }^{2}$ Department of Earth Sciences, Indian Institute of Technology, Bombay, Powai, Mumbai 400076, India \\ ${ }^{3}$ Wadia Institute of Himalayan Geology, 33 Gen. Mahadev Singh Road, Dehradun 248 001, India \\ Email: narottam1960@ gmail.com
}

\section{Introduction}

Kimberlites and lamproites in India are known to occur in the Dharwar Craton, Bastar Craton and Bundelkhand Craton (Fig. 1). These cratons are Archaean terranes comprising quartzofeldspathic gneisses and granitoids with Proterozoic platformal cover sequences in several parts. Kimberlites and lamproites in the Bastar Craton are confined to its eastern part near the contact with the Proterozoic Eastern Ghats Mobile Belt.

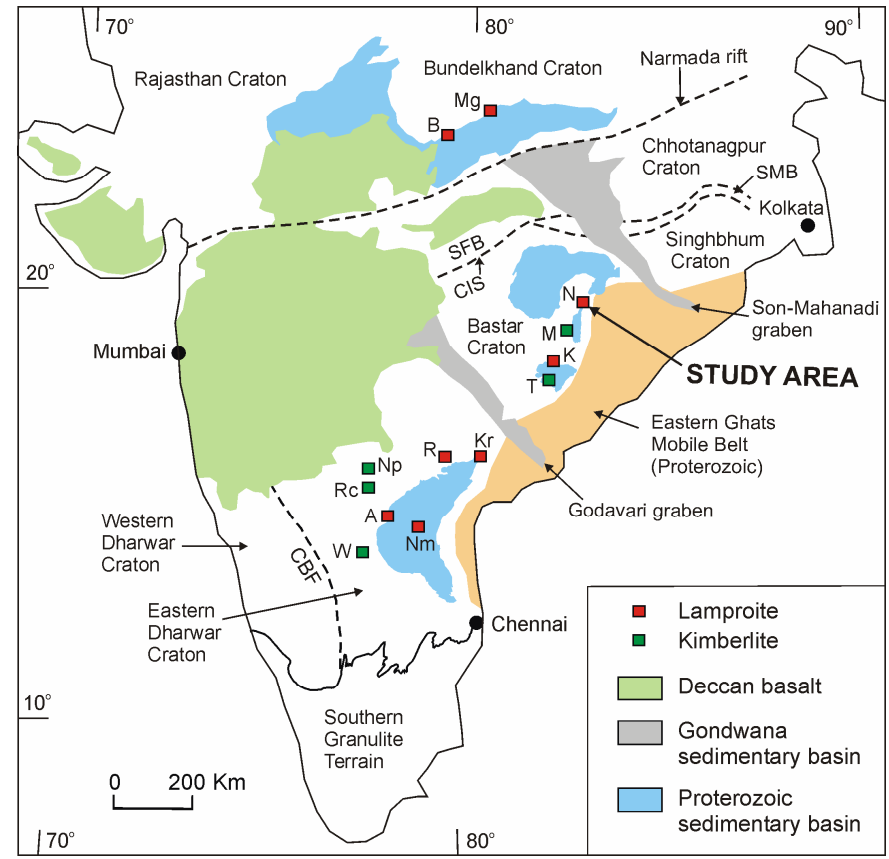

Fig.1. Schematic geological map of India. CBF - Chitradurga Boundary Fault; CIS - Central India Shear Zone; SFB - Satpura Fold Belt; SMB - Singhbhum Mobile Belt; A - Aliabad; B - Bunder; K Khadka; Kr - Krishna; M - Mainpur; Mg - Majhgawan; N Nuapada; Nm - Nallamalai; Np - Narayanpet; R - Ramadugu; Rc Raichur; T - Tokapal; W - Wajrakarur.
Kimberlites of the Bastar Craton are distributed in two fields, viz. Mainpur Kimberlite Field (MKF, diamondiferous), and Tokapal Kimberlite Field (barren). The MKF has six intrusions, while the TKF has two intrusions. Lamproites are known from two areas in the Bastar Craton, viz. Nuapada in Odisha and Khadka in Chhattisgarh. The Nuapada Lamproite Field (NLF) contains hypabyssal facies lamproite dykes at Kalmidadar and Darlimunda, and lamprophyre dykes at Amlidadar, Parkom and Darlimunda. The objectives of the present study are to: (i) examine the major element composition of mantle-derived spinel and garnet recovered from stream sediments and soil samples in the Kalmidadar area; and (ii) give the first mineralogical and geochemical data on the lamproites and lamprophyres of the NLF.

\section{Nuapada Lamproite Field}

The NLF is dominantly occupied by two types of Precambrian granitoids, viz. an older grey granitoid (weakly foliated) ( $2550 \mathrm{My}$ old), and a younger pink granitoid (unfoliated) (Fig. 2 ). The latter occupies the western part of the area and locally contains blocks of grey granite. Neoproterozoic platformal cover rocks of the Khariar basin are exposed in the southern part of the area and include sandstone (Devdahra Sandstone) and shale (Kulharighat Formation) of the Pairi Group.

The Kalmidadar lamproite (KD) $\left(82^{\circ} 22^{\prime} 20^{\prime \prime}: 20^{\circ} 45^{\prime}\right.$ $\left.10^{\prime \prime}\right)$ is a diamondiferous, $\mathrm{N}-\mathrm{S}$ trending, elongate body with surface dimension of $\sim 320 \mathrm{~m} \times 160 \mathrm{~m}$. It is completely weathered at the surface and weathering is persistent up to a depth of $12 \mathrm{~m}$ or more as revealed by drill cores. Its diamond grade is $9.95 \mathrm{cpht}$. The Darlimunda lamproite is a dyke swarm comprising several, mostly $\mathrm{N}-\mathrm{S}$ trending dykes marked by isolated, patchy hardebank exposures. Mukhopadhyay et al. (2004) considered the isolated exposures as individual dykes of lamproite and reported eight such dykes (I to VIII) in the Darlimunda area. However, our work shows that many of these small discontinuous exposures constitute parts of larger dyke systems. Furthermore, the dykes I and II of Mukhopadhyay et al. (2004) are not lamproites. While dyke I is a lamprohyre, dyke II is neither a lamproite nor a

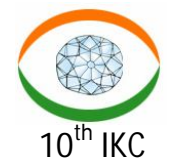




\section{$10^{\text {th }}$ International Kimberlite Conference-2012}

lamprophyre. We have grouped the dykes III to VIII of Mukhopadhyay et al. (2004) into two lamproite dyke systems (DM1 and DM2). The DM1 lamproite $\left(20^{\circ} 50^{\prime} 10^{\prime \prime} \mathrm{N}: 82^{\circ} 38^{\prime}\right.$ $20^{\prime \prime} \mathrm{E}$ ) is a broadly $\mathrm{N}-\mathrm{S}$ trending dyke with $\sim 5 \mathrm{~m} \times 150 \mathrm{~m}$ size. Near the southern end of this dyke, a small, NE-SW trending dyke $\left(20^{\circ} 50^{\prime} 09^{\prime \prime} \mathrm{N}: 82^{\circ} 38^{\prime} 13^{\prime \prime} \mathrm{E}\right)$ of $\sim 2 \mathrm{~m} \times 20 \mathrm{~m}$ size occurs. This small dyke corresponds to the dyke VI, whereas the main DM1 dyke includes the dykes VII and VIII of Mukhopadhyay et al. (2004). The DM2 lamproite $\left(20^{\circ} 50^{\prime}\right.$ $00^{\prime \prime} \mathrm{N}: 82^{\circ} 38^{\prime} 32^{\prime \prime} \mathrm{E}$ ) is a broadly $\mathrm{N}-\mathrm{S}$ trending dyke with an average width of $\sim 5 \mathrm{~m}$ and length of $\sim 130 \mathrm{~m}$. Hardebank outcrops are patchy and sparse in this dyke and the granitoid country rock is veined by thin, irregular apophyses of lamproite originating from the main intrusion. This intrusion includes the dykes III, IV and V of Mukhopadhyay et al. (2004).

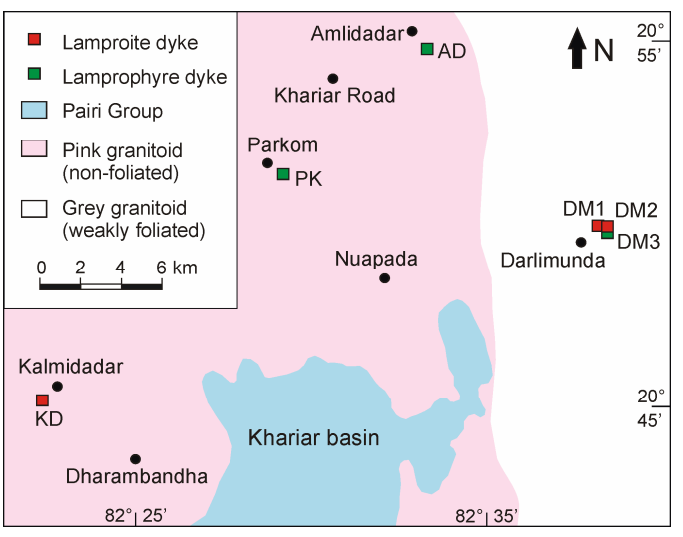

Fig.2. Generalised geological map of Nuapada Lamproite Field. AD - Amlidadar; DM - Darlimunda; KD - Kalmidadar; PK - Parkom.

The dyke I of Mukhopadhyay et al. (2004) is named here DM3 lamprophyre $\left(20^{\circ} 49^{\prime} 54^{\prime \prime} \mathrm{N}: 82^{\circ} 38^{\prime} 22^{\prime \prime} \mathrm{E}\right)$, which exhibits an $\mathrm{E}-\mathrm{W}$ trend with $\sim 3 \mathrm{~m} \times 25 \mathrm{~m}$ size. The Amlidadar lamprophyre (AD) $\left(20^{\circ} 54^{\prime} 52^{\prime \prime} \mathrm{N}: 82^{\circ} 33^{\prime} 11^{\prime \prime} \mathrm{E}\right)$ is a $\mathrm{N}-\mathrm{S}$ trending dyke of $\sim 1 \mathrm{~m} \times 40 \mathrm{~m}$ size. The Parkom lamprophyre (PK) $\left(20^{\circ} 51^{\prime} 32^{\prime \prime} \mathrm{N}: 82^{\circ} 29^{\prime} 11^{\prime \prime} \mathrm{E}\right)$ is a thin ( $0.5 \mathrm{~m}$ wide), $\mathrm{N}-\mathrm{S}$ trending dyke of $15 \mathrm{~m}$ length. The dykes $\mathrm{AD}$ and $\mathrm{PK}$ correspond to the dykes IX and X, respectively of Mukhopadhyay et al. (2004), who considered these bodies as lamproites. However, our mineralogical study shows that these bodies are not lamproites. A mafic dyke at Sakri, reported by Shrivastava et al. (2002) as lamproite, has been found to be dolerite.

\section{Age of Nuapada lamproites}

Whole rock Ar-Ar isotopic analysis of two samples, one each from the Kalmidadar and Darlimunda lamproites, was carried out by Thermo Fischer Scientific ARGUS-VI Mass Spectrometer at the Indian Institute of Technology, Bombay.
Both the rocks yielded saddled-shaped patterns with a plateau age of $1030 \pm 20 \mathrm{My}$. This represents the crystallisation age of the lamproites which assumes significance in view of the fact that Lehmann et al. (2010) dated two kimberlites of the MKF as 65 My old.

\section{Indicator mineral chemistry}

Gravel samples collected during regional indicator mineral survey and soil samples collected during detailed survey were processed for recovery of heavy minerals. Cr-spinel was abundant in the intermediate magnetic fraction, whereas garnet was occasionally found in the non-magnetic fraction. Picroilmenite and Cr-diopside were not found in any of the samples. Cr-spinel grains are elongated to subrounded in shape with beveled edges and exhibit concave fracture and micropitted surface. They appear fresh worn to worn. Garnet grains are purple to wine-red in colour with frosted to scaly frosted surface. They exhibit strong internal colour change (firing) and subconchoidal fracture.

This study examines the compositions of 54 spinels and 9 garnets from the indicator mineral suite on and around Kalmidadar lamproite. The minerals were analyzed by Oxford ISIS EDS attached to a JEOL6400 SEM at the Centre for Microscopy Characterisation and Analysis, University of Western Australia, Crawley, Western Australia.

The Kalmidadar Cr-spinels show wide variations in $\mathrm{Cr}_{2} \mathrm{O}_{3}$ (33-67 wt \%, mostly above $50 \mathrm{wt} \%$ ), $\mathrm{Al}_{2} \mathrm{O}_{3}$ (5-38 $\mathrm{wt} \%$.), $\mathrm{MgO}(11-18 \mathrm{wt} \%)$ and $\mathrm{FeO}^{\mathrm{T}}(9-20 \mathrm{wt} \%)$. They have low $\mathrm{TiO}_{2}$ content $(<1 \mathrm{wt} \%)$ except for a few grains with up to $2.4 \mathrm{wt} \% \mathrm{TiO}_{2}$. Stoichiometric calculations yield very low ferric iron in the $\mathrm{Cr}$-spinels with $\mathrm{Fe}^{3+} /\left(\mathrm{Cr}+\mathrm{Al}+\mathrm{Fe}^{3+}\right)$ ratios below 0.06 . Their $\mathrm{X}_{\mathrm{Mg}}\left(=\mathrm{Mg} / \mathrm{Mg}+\mathrm{Fe}^{2+}\right)$ ratio falls in the range of $0.49-0.77$, while the $\mathrm{Cr} \#[=\mathrm{Cr} /(\mathrm{Cr}+\mathrm{Al})]$ varies from 0.52 to 0.91 except for a few grains with values between 0.38-0.48. Majority of the $\mathrm{Cr}$-spinel population can be classified as $\mathrm{Ti}$ poor, aluminous magnesiochromite. In the $\mathrm{MgO}-\mathrm{Cr}_{2} \mathrm{O}_{3}$ plot the Kalmidadar $\mathrm{Cr}$-spinels exhibit a negatively sloping trend and extend into the diamond inclusion field consistent with their diamondiferous association (Fig. 3). On a plot of $\mathrm{Cr} /(\mathrm{Cr}+\mathrm{Al}) \mathrm{vs} \mathrm{Fe}^{2+} /\left(\mathrm{Mg}+\mathrm{Fe}^{2+}\right)$, the $\mathrm{Cr}$-spinels show an overall tendency of increasing $\mathrm{Cr}$-number with increasing $\mathrm{Fe}^{2+} /\left(\mathrm{Mg}+\mathrm{Fe}^{2+}\right)$ (Fig. 4). This trend, known as the $\mathrm{Cr}-\mathrm{Al}$ trend, could be a high- to low-pressure trend if spinel compositions in mantle peridotitic source were controlled by Al-exchange with coexisting pyroxenes (Barnes and Roeder, 2001).

The Kalmidadar garnets have $\mathrm{Mg} \#\left[=\mathrm{Mg} /\left(\mathrm{Mg}+\mathrm{Fe}^{\mathrm{T}}\right)\right]$ in a narrow range of $0.83-0.88$. Their $\mathrm{Cr}_{2} \mathrm{O}_{3}$ content varies significantly between $1.4-7.2 \mathrm{wt} \%$, while the $\mathrm{CaO}$ content falls in the range of 4.6-6.1 wt\%. In the $\mathrm{MgO}-\mathrm{CaO}-\mathrm{Cr}_{2} \mathrm{O}_{3}$ diagram the Kalmidadar pyropes fall in the G9 (lherzolitic garnet) field (Fig. 5). On $\mathrm{Cr}_{2} \mathrm{O}_{3}$ vs $\mathrm{CaO}$ plot, the pyropes follow the typical lherzolitic trend, which reveals that the garnets were derived from a lherzolitic mantle source (Fig. 6).

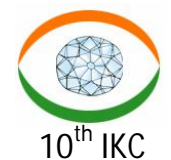




\section{$10^{\text {th }}$ International Kimberlite Conference-2012}

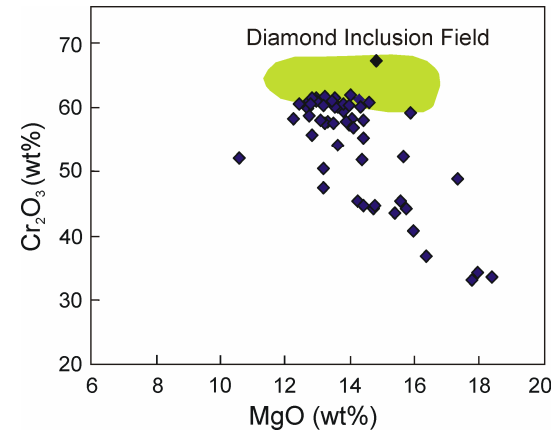

Fig.3. $\mathrm{MgO}-\mathrm{Cr}_{2} \mathrm{O}_{3}$ plot of Kalmidadar $\mathrm{Cr}$ spinels. Diamond inclusion field after Fipke et al. (1995).

Fig.4. Kalmidadar $\mathrm{Cr}$ spinels on $\mathrm{Cr} /(\mathrm{Cr}+\mathrm{Al})$ vs $\mathrm{Fe}^{2+} /\left(\mathrm{Mg}+\mathrm{Fe}^{2+}\right)$ diagram.
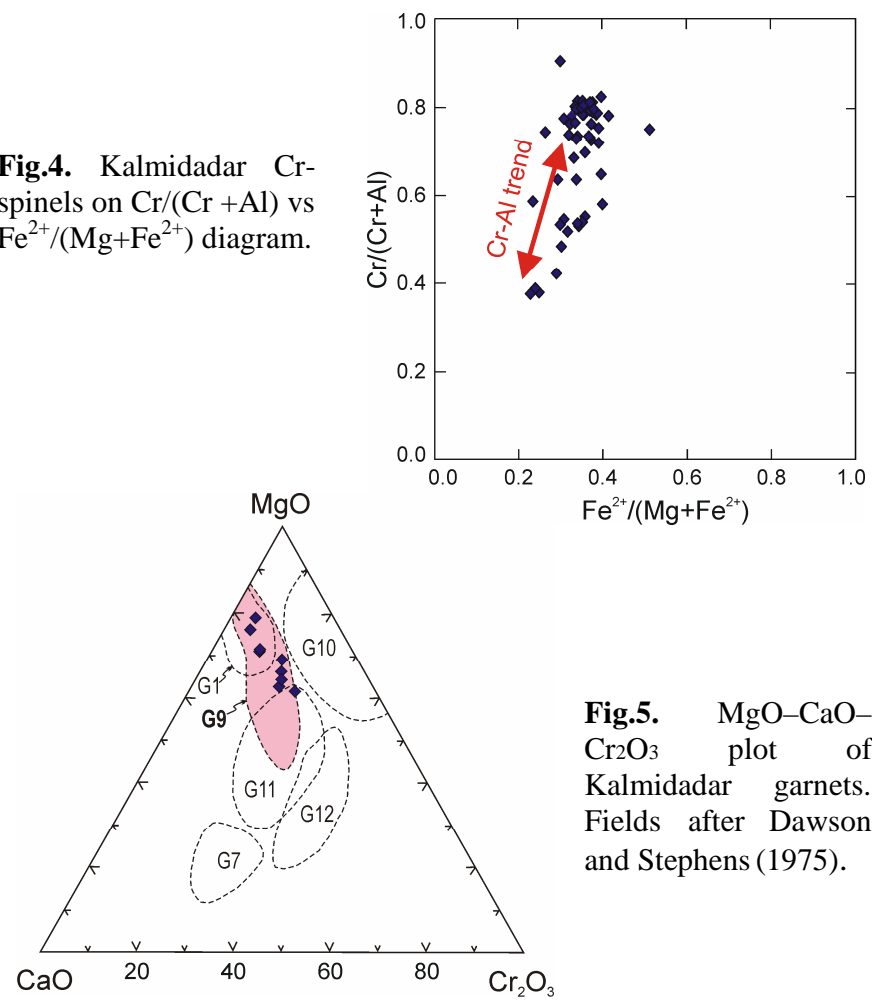

Fig.5. $\mathrm{MgO}-\mathrm{CaO}-$ $\mathrm{Cr}_{2} \mathrm{O}_{3}$ plot of Kalmidadar garnets. Fields after Dawson and Stephens (1975).

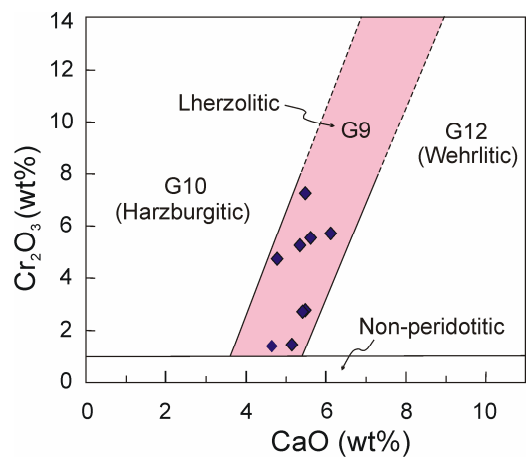

Fig.6. Kalmidadar garnets on $\mathrm{CaO}$ vs $\mathrm{Cr}_{2} \mathrm{O}_{3}$ plot. Fields of harzburgitic, lherzolitic and wehrlitic garnets after Grutter et al. (2004).

Mantle phase equilibria considerations show that the subsolidus transition of spinel peridotite to garnet peridotite occurs via the generalised reaction: spinel + pyroxene $(s)=$ garnet + olivine. In the chemical system $\mathrm{MgO}-\mathrm{Al}_{2} \mathrm{O}_{3}-\mathrm{Cr}_{2} \mathrm{O}_{3}-$
$\mathrm{SiO}_{2}$, a pressure-temperature field exists where garnet and spinel coexist. The width of this divariant field strongly depends on the $\mathrm{Cr} /(\mathrm{Cr}+\mathrm{Al})$ of the system, and with increasing value of this ratio the spinel-garnet transition progressively shifts to pressures as high as $~ 70$ kbar (i.e., depth of $\sim 200$ $\mathrm{km}$ ) (Klemme, 2004). From the high Cr\# of Kalmidadar Crspinels, it can be said that they are derived from sources as deep as $200 \mathrm{~km}$.

\section{Mineralogy of lamproites and lamprophyres}

Since the Kalmidadar lamproite is completely weathered at the surface, the studied samples are from bore holes (up to $30 \mathrm{~m}$ depth) drilled by the Directorate of Geology, Government of Odisha. Samples from all other bodies are from surface exposures. Mineralogically, the Kalmidadar lamproite comprises phenocrysts $(0.5-1 \mathrm{~mm})$ of olivine (pseudomorphed by calcite and talc) and microphenocrysts $(0.1-0.3 \mathrm{~mm})$ of phlogopite set in a groundmass of secondary chlorite and calcite (Fig. 7). The Darlimunda lamproites (DM1 and DM2) have undergone pervasive hydrothermal and/or deuteric alteration, which has resulted in complete chloritisation of phlogopite microcrysts and groundmass flakes and extensive silicification of the rocks. Phenocrysts of olivine in the Darlimunda lamproites are mostly pseudomorphed by quartz. However, relicts of the primary textures are well-preserved thereby providing important clues to the mineralogy and nature of the protolith. Tiny grains of rutile and apatite are commonly scattered in the groundmass of both Kalmidadar and Darlimunda lamproites. Rutile often occurs as relict within silicified micro-nodules of variable $\mathrm{TiO}_{2}-\mathrm{SiO}_{2}$ composition. A rare subhedral grain of zircon $(0.25 \mathrm{~mm}$ long) was observed in a slide of Kamlidadar lamproite. Microcrysts of titanite occur locally in the Kalmidadar lamproite, but are common in the Darlimunda lamproites.

The Amlidadar lamprophyre is broadly similar in mineralogy to the Kalmidadar lamproite, except that: (i) mica is mostly biotite instead of phlogopite; (ii) secondary talc is absent; and (iii) secondary pyrite is present. The Parkom lamprophyre comprises phenocrysts of olivine (pseudomorphed by calcite) set in a groundmass of acicular diopside and flaky biotite. Diopside and phlogopite occasionally form phenocrysts and microphenocrysts, respectively in this rock.

Minerals in the lamproites and lamprophyres were analysed by Cameca SX-100 electron microprobe at the Wadia Institute of Himalayan Geology, Dehradun. Phlogopites in the Kalmidadar lamproite have a compositional range of 5.4-7.4 wt\% $\mathrm{TiO}_{2}, 8.6-11.2 \mathrm{wt} \% \mathrm{Al}_{2} \mathrm{O}_{3}, 7.3-9.2 \mathrm{wt} \%$ $\mathrm{FeO}^{\mathrm{T}}$. Their $\mathrm{Mg} \#$ falls in the range of $0.80-0.83$ (Fig. 8). The range of $\mathrm{Mg \#}$ in biotites of Amlidadar lamprophyre is $0.37-$ 0.68 , while that in biotites of Parkom lamprophyre is $0.27-$ 0.44 . The Ba content of Kalmidadar phlogopites and Parkom biotites is low $(<0.5 \mathrm{wt} \% \mathrm{BaO})$, whereas that of Amlidadar 


\section{$10^{\text {th }}$ International Kimberlite Conference-2012}

biotites is relatively high (2-3.6 wt\% $\mathrm{BaO})$. Diopside in the Parkom lamprophyre is rich in both $\mathrm{Al}\left(2.7-4.4 \mathrm{wt} \% \mathrm{Al}_{2} \mathrm{O}_{3}\right)$ and $\mathrm{Ti}\left(2.6-3.9 \mathrm{wt} \% \mathrm{TiO}_{2}\right)$, while its $\mathrm{Na}_{2} \mathrm{O}$ content is low $(<$ $0.5 \mathrm{wt} \%)$. Rutile in the lamproites and lamprophyres contains up to $2.6 \mathrm{wt} \% \mathrm{Nb}_{2} \mathrm{O}_{5}$ and up to $0.5 \mathrm{wt} \% \mathrm{ZrO}_{2}$.

The Amlidadar and Parkom rocks are named lamprophyre instead of lamproite because their mica is biotite instead of phlogopite, and the Parkom diopside is Al-rich. Mineralogically, the Kalmidadar and Darlimunda lamproites range from olivine phlogopite lamproite to phlogopite lamproite.

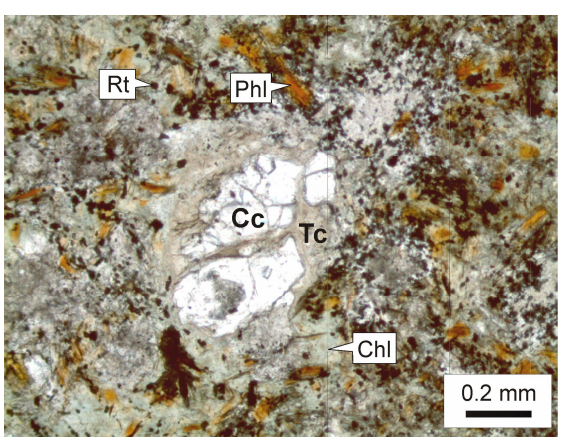

Fig.7. Photomicrograph of Kalmidadar lamproite under plane polarized light. Calcite (Cc) and talc (Tc) occur in pseudomorph after olivine phenocryst. Phlogopite (Phl) forms microphenocrysts. Groundmass comprises chlorite $(\mathrm{Chl})$ and calcite with scattered grains of rutile ( $\mathrm{Rt}$ ), which is altered to $\mathrm{TiO}_{2}-\mathrm{SiO}_{2}$ micro-nodules.

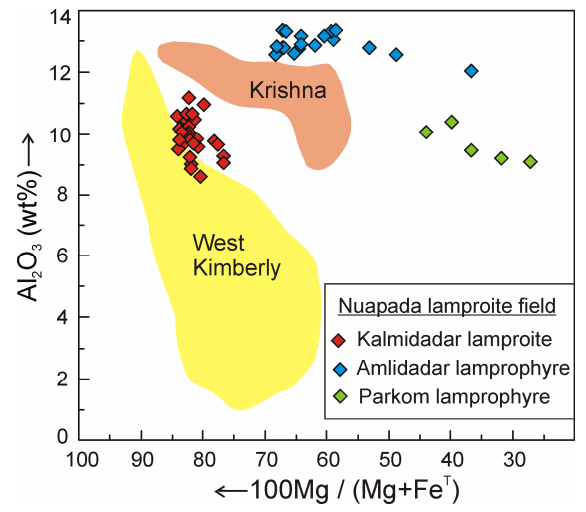

Fig.8. Compositional variation of mica in Nuapada lamproites and lamprophyres compared with that in Krishna lamproites, southern India (Reddy et al., 2003; Chalapathi Rao et al., 2010) and West Kimberly lamproites (Mitchell and Bergman, 1991 and references therein).

Mica grains in the Nuapada lamproites and lamprophyres often show chemical zoning marked by a narrow Fe-rich rim relative to the core. All the micas have appreciable tetraferric component since their $(\mathrm{Si}+\mathrm{Al})$ content is $<8$ pfu (Fig. 9). Relationship between Ti content and octahedral site deficiency indicates two important substitution mechanisms in accommodating $\mathrm{Ti}$ in the micas, viz. $\mathrm{Ti}+\square \leftrightarrow 2 \mathrm{Mg}$, and $\mathrm{Ti}+$ $2 \mathrm{Al} \leftrightarrow \mathrm{Mg}+2 \mathrm{Si}$ (Fig. 10). In terms of compositional range of phlogopite, the Kalmidadar lamproite is closer to the West Kimberly lamproites than to the Krishna lamproites.

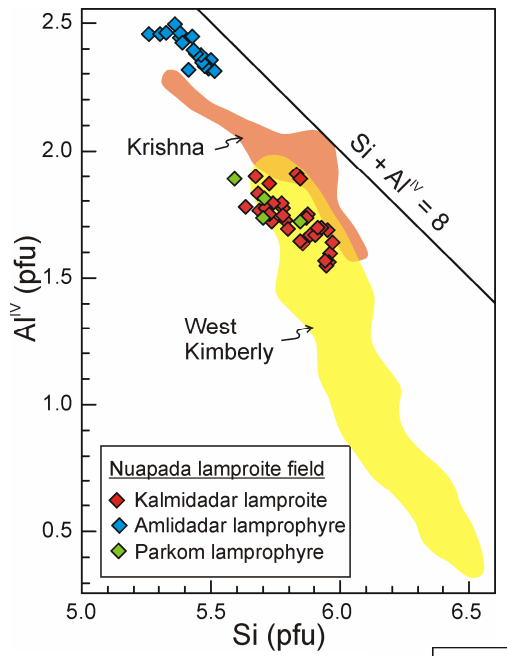

Fig.9. Tetrahedral Al vs $\mathrm{Si}$ plot for Nuapada micas. Data fources for compositional fields same as in Fig. 8.

Fig.10. Nuapada micas on a plot of $\mathrm{Ti}$ vs Octahedral Occupancy (OSO). Data sources for compositional fields same as in Fig. 8.

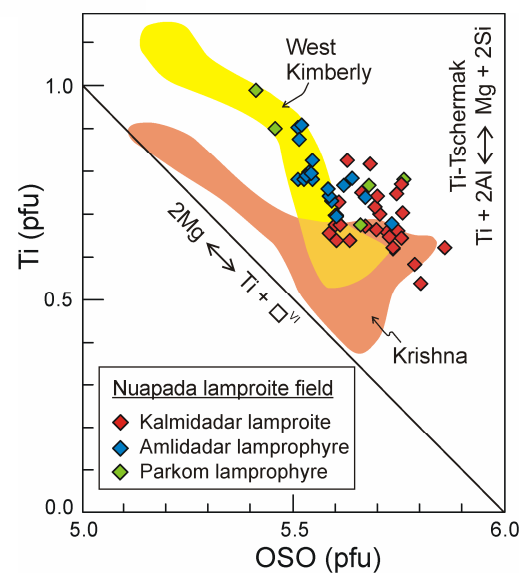

\section{Geochemistry}

Bulk rock analyses of 5 samples of lamproites (2 from Kalmidadar and 3 from Darlimunda), and 3 samples of lamprophyres (1 each from Amlidadar, Parkom and Darlimunda) were carried out. Major elements and rare earth elements (preconcentrated via ion exchange resin), were analysed by Jobin Yvon Ultima-2 ICP-AES, and other trace elements by Phillips PW-2404 WD-XRF at the Indian Institute of Technology, Bombay.

The Nuapada lamproites have variable $\mathrm{SiO}_{2}$ (44-60 wt\%) content with higher values observed in rocks that are more silicified. The $\mathrm{K}_{2} \mathrm{O}$ content of the rocks is generally low $(<0.4$ wt\%), which is attributed to chloritisation of phlogopite and consequent loss of $\mathrm{K}_{2} \mathrm{O}$ to a hydrothermal fluid. The highest value of $\mathrm{K}_{2} \mathrm{O}(1.34 \mathrm{wt} \%)$ is observed in a borehole sample from the Kalmidadar lamproite, which is rich in unaltered 


\section{$10^{\text {th }}$ International Kimberlite Conference-2012}

phlogopite. The Nuapada lamproites have highly variable contents of $\mathrm{MgO}$ (7.4-14.3 wt\%), $\mathrm{FeO}^{\mathrm{T}}$ (7.2-11.1 wt\%), $\mathrm{CaO}$ (2.2-12.3 wt \%), $\mathrm{TiO}_{2}(2.6-7.4 \mathrm{wt} \%)$ and $\mathrm{P}_{2} \mathrm{O}_{5}(0.1-1.9 \mathrm{wt} \%)$, while their $\mathrm{Al}_{2} \mathrm{O}_{3}$ content falls within a narrow range of 5.3$7.2 \mathrm{wt} \%$. The lamprophyres have similar ranges of $\mathrm{SiO}_{2}$, $\mathrm{Al}_{2} \mathrm{O}_{3}, \mathrm{CaO}, \mathrm{TiO}_{2}$ and $\mathrm{P}_{2} \mathrm{O}_{5}$ as the lamproites, but are richer in $\mathrm{FeO}^{\mathrm{T}}(14.6-17.2 \mathrm{wt} \%)$, while having relatively low but uniform value of $\mathrm{MgO}(\sim 8.7 \mathrm{wt} \%)$. Their $\mathrm{K}_{2} \mathrm{O}$ content is low except for the Parkom lamprophyre $\left(2.7 \mathrm{wt} \% \mathrm{~K}_{2} \mathrm{O}\right)$, which is rich in unaltered phlogopite.

The Nuapada lamproites have high contents of compatible elements such as V (215-347 ppm), Cr (257-478 ppm) and $\mathrm{Ni}$ (232-423 ppm) as well as of incompatible elements such as Ba (2292-3499 ppm), Zr (544-780 ppm), Nb (52-135 ppm) and $\mathrm{Hf}$ (13-19 ppm). $\mathrm{Zr}$ and $\mathrm{Hf}$ behave coherently with an average $\mathrm{Zr} / \mathrm{Hf}$ ratio of 42 . The lamproites show high abundance of REE ( $\sum$ REE $\left.=790-1335 \mathrm{ppm}\right)$ and enrichment in LREE relative to $\operatorname{HREE}\left[(\mathrm{La} / \mathrm{Yb})_{\mathrm{N}}=34-108\right]$ (Fig. 11A).
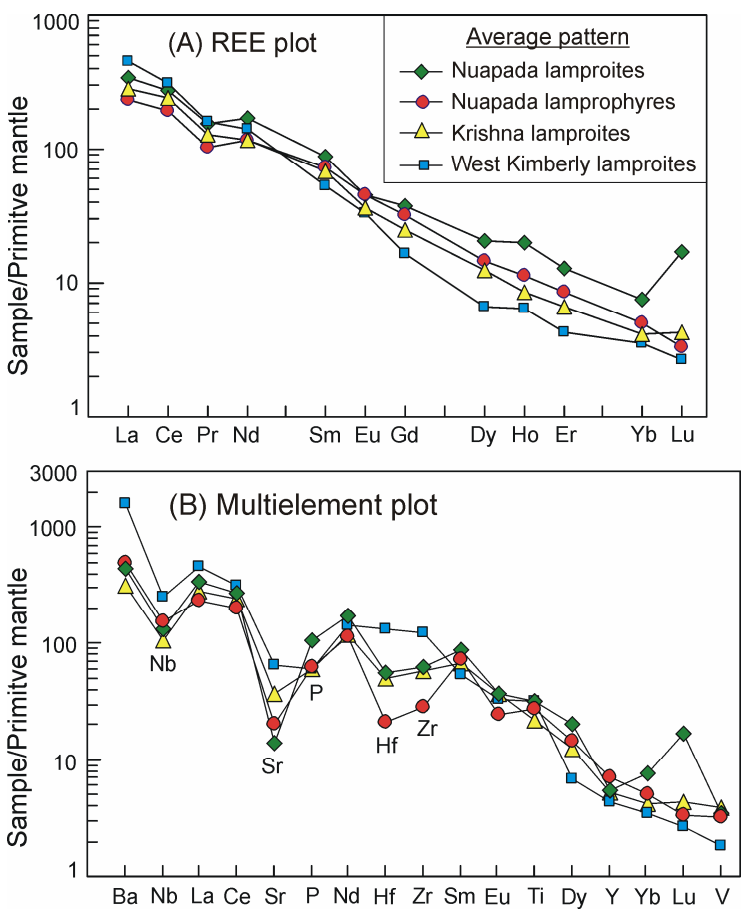

Fig.11. Primitive mantle normalised patterns of (A) rare earth elements and (B) multielements, in average Nuapada lamproite and average Nuapada lamprophyre compared with those of average Krishna lamproite (Vijesh, 2010) and average West Kimberly lamproite (Mitchell and Bergman, 1991 and references therein).

The Nuapada lamprophyres have similar contents of $\mathrm{V}$, $\mathrm{Cr}, \mathrm{Ba}$ and $\mathrm{Nb}$ as the lamproites, but are relatively poor in $\mathrm{Ni}$ (166-221 ppm), Zr (218-349 ppm) and Hf (4-9 ppm). Both the lamproites and lamprophyres usually have low $\mathrm{Rb}$ content ( $<13$ ppm), which correlates well with their low $\mathrm{K}_{2} \mathrm{O}$ content that was caused by chloritisation of phlogopite. The lamprophyres have lower abundance of REE $\left(\sum \mathrm{REE}=524\right.$ $1111 \mathrm{ppm}$ ) than the lamproites, although their patterns are similar and comparable to those of Krishna lamproites of southern India and West Kimberly lamproites of Australia.

In terms of incompatible element distribution patterns marked by negative $\mathrm{Nb}, \mathrm{Sr}$ and $\mathrm{P}$ anomalies relative to REE, the Nuapada lamproites and lamprophyres are broadly similar to Krishna lamproites and West Kimberly lamproites (Fig. 11B). The Nuapada and Krishna rocks are additionally marked by depletion in $\mathrm{Zr}$ and $\mathrm{Hf}$ relative to REE which is absent in the West Kimberly lamproites. While the Nuapada and Krishna lamproites have similar degrees of depletion in $\mathrm{Zr}$ and Hf, the Nuapada lamprophyres exhibit somewhat higher degree of depletion in these elements.

\section{References}

Barnes, S.J. and Roedder, P.L. (2001) The range of spinel compositions in terrestrial mafic and ultramafic rocks. Jour. Petrol., v.42, pp.2279-2302.

Chalapathi Rao, N.V., Kamde, G., Kale, H.S. and Dongre, A. (2010) Petrogenesis of the Mesoproterozoic Lamproites from the Krishna Valley, Eastern Dharwar Craton, Southern India. Prec. Res., v.177, pp.103-130.

Dawson, J.B. and Stephens, W.E. (1975) Statistical classification of garnets from kimberlite and associated xenoliths. Jour. Geol., v.83, pp.589-607.

Fipke, C.E., Gurney, J.J. and Moore R.O. (1995) Diamond exploration techniques emphasizing indicator mineral geochemistry and Canadian examples. Geol. Surv. Canada Bull. 423.

Grütter, H.S., Gurney, J.J., Menzies, A.H. and Winter, F. (2004) An updated classification scheme for mantle-derived garnet, for use by diamond explorers. Lithos, v.77, pp.841-857.

Klemme, S. (2004) The influence of $\mathrm{Cr}$ on the garnet-spinel transition in the Earth's mantle: experiments in the system $\mathrm{MgO}-\mathrm{Cr}_{2} \mathrm{O}_{3}-$ $\mathrm{SiO}_{2}$ and thermodynamic modeling. Lithos, v.77, pp.639-646.

Lehmann, B., Burgess, R., Frei, D., Belyatsky, B., Mainkar, D., Chalapathi Rao, N.V., Heaman, L.M. (2010) Diamondiferous kimberlites in central India synchronous with Deccan flood basalts. Earth Planet. Sci. Lett., v.290, pp.142-149.

Mitchell, R.H. and Bergman, S.C. (1991) Petrology of Lamproites. Plenum Press, New York, 447p.

Mukhopadhyay, P.K., Ghosh, S., Rath, S.C., Swain, R.B. and Shome, S. (2004) New finds of lamproite dykes in Nawapara district, Orissa. Indian Minerals, v.58, pp.183-196.

Reddy, T.A.K., Sridhar, M., Ravi, S., Chakravarthi, V. and Neelakantam, S. (2003) Petrography and geochemistry of the Krishna Lamproite Field, Andhra Pradesh. Jour. Geol. Soc. India, v.61, pp.131-146.

Shrivastava , S.K., Roy, A., Thakur, K.S., Muthuraman, K. and Khotpal, A.S. (2002). Discovery of lamproites by application of airborne geophysical techniques in eastern part of Bastar Craton. Geol. Surv. India Spl. Pub. No.75, pp.119-127.

Vijesh, V.K. (2010) Petrology of lamproites from the Krishna Lamproite Field, Andhra Pradesh. Unpub. M.Tech. (Geoexploration) thesis, IIT Bombay, 65p. 